\title{
Analysis of Factors That Affect the Financial Performance of Banks
}

\author{
Yenni Vera Fibriyanti*1, Lilik Nurcholidah ${ }^{2}$ \\ ${ }^{1}$ Univeristas Islam Lamongan, Indonesia \\ *Email corresponding authors: Yennivera58@gmail.com
}

\begin{abstract}
Stakeholders analyze financial reports to assess the financial performance of banks which are used for making decisions (investing). This study aims to analyze the factors that affect the financial performance appraisal of the national foreign exchange private commercial bank and to analyze the effect of car, npl, roa, nim, and bopo partially and simultaneously on the financial performance of the national foreign exchange national private commercial bank. The population in this study were all national foreign exchange commercial banks that have gone public and published their financial reports on their official website or that have reported their finances to bank indonesia in the banking directory. The analysis technique used is financial analysis techniques, descriptive analysis techniques and differential statistical analysis techniques. The factors that affect financial performance can be analyzed using the $t$ test and the $f$ test. The results show that npl has the most dominant influence on the financial performance of private banks.
\end{abstract}

\section{Keywords: CAR, NPL, ROA, NIM, LDR, Financial Performance}

\section{INTRODUCTION}

In an effort to support the 4.0 industrial revolution where all businesses experience dependence on the economy, banking institutions have shown very rapid development. Based on data from the Bank Info Research Bureau [5], the banking industry controls $84 \%$ of the financial market share in Indonesia, followed by the insurance industry $5.39 \%$, pension funds $4.7 \%$, the financing industry $3.32 \%$, securities $1.9 \%$, and pawnshops, $0.5 \%$. The large number of new banks led to intense competition so that the new banks had to share the rest of the predecessor banks. This of course will cause many banks to become fragile because they are unable to compete.

With the development of this banking sector, the interest of stakeholders and parties with an interest in the banking sector will also develop to invest. Financial reports are very important for internal and external parties to determine the financial condition of banks. With financial reports, parties with an interest in banking can assess the financial performance of banks, so that they are used as a basis for decision making.

From the above background, it is necessary to have factors that influence the assessment of banking financial performance. These factors include the Capital Adequacy Ratio (CAR), Non-Performing
Loans (NPL), Return on Assets (ROA), Net Interest Margin (NIM), and Loan to Deposit Ratio (LDR). The objectives of this study are: (1) To analyze the factors that influence the financial performance assessment of Conventional Commercial Banks, (2) To analyze the effect of CAR, NPL, ROA, NIM, and LDR partially and simultaneously on the financial performance of Conventional Commercial Banks, (3) To analyze the factors the most dominant influence on the financial performance of Conventional Commercial Banks.

\section{LITERATURE REVIEW}

Prastowo [6] states "that financial ratios are ratios that describe the company's financial condition by looking for relationships between items in the financial statements". The use of financial ratios will explain and provide an overview of the good and bad condition of the company's financial position by comparing the current ratio with future ratios [3]. Ratio analysis can be classified into five groups, namely: (1) Liquidity ratios, (2) Solvency ratio, (3) Rentability ratio or Profitability, (4) Asset Utilization ratio and (5) Operating Performance ratio.

The CAR ratio shows the capital adequacy of a bank to overcome current risks and anticipate future risks [1]. CAR is a capital ratio that shows a bank's ability to provide funds for business development needs and 
accommodate the risk of loss of funds caused by bank operations.

Non-Performing Loans (NPL) show that the ability of bank management to manage non-performing loans provided by banks. Non-performing loans are loans with substandard, doubtful and bad quality [4]. The higher the NPL, the worse the quality of bank credit.

Return on Assets (ROA) is used to measure the ability of bank management in obtaining overall profits. The greater the ROA of a bank, the greater the level of profit achieved by the bank and the better the position of the bank in terms of asset use [4].

Net Interest Margin (NIM) is the ratio between net interest income and average earning assets. Net interest income is derived from interest income less interest expense. Earning assets that are calculated are earning assets that generate interest (interest bearing assets) [10]. The greater this ratio, the increase in interest income on productive assets managed by the bank so that the possibility of a bank in a problematic condition is getting smaller.

This Loan to Deposit ratio (LDR) measures the ability to throw funds based on a certain source of funds. This ratio is similar to the asset / liability ratio for an ordinary company. Credit loans are usually the largest and most important asset for banks, while deposits are an important and largest source of funds for banks. The higher this number the less liquid the bank is, because most of the funds are embedded in loans. If there is a withdrawal of funds by a depositor, the bank can run into difficulties. On the other hand, the higher this figure, the greater the profitability of the bank, because the bank is able to disburse funds more effectively [8].

According to Rivai [7], Loan to Deposit ratio (LDR) is a ratio that measures the ratio of the amount of credit provided by the bank to the funds received by the bank, which describes the bank's ability to repay deposit withdrawals by relying on the credit provided as a source of liquidity. Therefore, the higher the ratio, an indication of the low liquidity capacity of the bank, this is as a result of the larger amount of funds needed to finance credit.
According to Fahmi [3] "financial performance is an analysis carried out to see the company's success in managing the organization as a whole which is adjusted to the proper and correct financial implementation rules". From the above opinion it can be interpreted that financial performance is an assessment of how well the results achieved by the company in achieving economic goals, where the goal of the economy is to maximize the welfare of the people.

\section{RESEARCH METHODS}

The type of research used is descriptive quantitative research, which is research that analyzes data by describing or describing the collected data as is without the intention of making generalized conclusions and generalizations [9]. The population in this study are all commercial banks in Indonesia and publish their financial reports on their official website or those that have reported their finances to Bank Indonesia in the Banking Directory. The sampling method was purposive sampling, in which the sample was selected based on certain criteria. The criteria referred to are: (1) Conventional Commercial Banks publish their financial reports on the Indonesia Stock Exchange (IDX) during 2015-2019. (2) Conventional Commercial Banks which consistently report financial reports annually and publish them on the IDX website www.bi.go.id 2015-2019. (3) Has complete financial reports (especially items that can be calculated by financial ratios).

Data analysis techniques used in this study include classical assumption test, multiple regression analysis, hypothesis testing. The classical assumption test consists of normality test, multicollinearity test, heteroscedasticity test, and auto correlation test. Meanwhile, to test the hypothesis using the $t$ statistical test, the coefficient of determination test, and the F test.

\section{RESEARCH RESULTS AND DISCUSSION}

The results of the research in this study are as follows:

\subsection{Multiple Linear Analysis Test}


Table 1. Multiple Linear Regression Test Results

\begin{tabular}{|c|c|c|c|c|c|c|}
\hline & & Unstandardiz & Coefficients & $\begin{array}{c}\text { Standardized } \\
\text { Coefficients }\end{array}$ & & \\
\hline & & $\mathrm{B}$ & Std. Error & Beta & $\mathrm{T}$ & Sig. \\
\hline 1 & (Constant) & ,891 & 2,960 & & 2,218 &, 029 \\
\hline & CAR (X1) &, 303 &, 110 &, 250 & 2,762 &, 007 \\
\hline & NPL (X2) &, 421 &, 091 &, 424 & 4,614 &, 000 \\
\hline & ROA (X3) & ,249 &, 098 & ,208 & 2,554 &, 012 \\
\hline & NIM (X4) &, 377 &, 094 &, 300 & 3,987 &, 000 \\
\hline & LDR (X5) & ,304 &, 125 & ,287 & 2,427 &, 018 \\
\hline
\end{tabular}

Source: Spss 26 Output Results

The results of the multiple regressions that the researchers conducted in the variables CAR, NPL, ROA, NIM, and LDR have a significant effect on Bank Financial Performance (Y), it is known that the value can be described by the multiple regression equation as follows:

$\mathrm{Y}=\mathrm{a}+\mathrm{b} 1 \mathrm{X} 1+\mathrm{b} 2 \mathrm{X} 2+\mathrm{b} 2 \times 3+\mathrm{b} 3 \mathrm{X} 3+\mathrm{b} 4 \mathrm{X} 4+$ b5X5c

$\mathrm{Y}$ value $=0.891+0.303 \mathrm{X} 1+0.421 \mathrm{X} 2+0.249 \mathrm{X} 3+$ $0.377 \mathrm{X} 4+0.304 \mathrm{X} 5$

\subsection{T test}

Based on the results of the $t$ test above with a significant value $\alpha=0.05(0.05 / 2=0.025) \mathrm{df}=\mathrm{n}-\mathrm{k}-1$ $(25-5-1=19)$ obtained $t$ table $(2.093)$, with the following analysis:

\subsubsection{CAR}

From the t test, it was obtained that $\mathrm{t}$ count (2.762) was greater than $t$ table (2.093). So that tcount $>$ ttable then $\mathrm{H} 1$ is accepted. From these data, the value of tcount $>$ ttable $(2.762>2.093)$ can be concluded, so it can be concluded that partially the CAR variable (X1) has a significant effect on bank financial performance $((\mathrm{Y})$.

\subsection{2. $\quad N P L$}

From the t test, it is obtained that tcount (4.614) is greater than ttable (2.093). So that tcount $>$ ttable then H1 is accepted. From these data, the value of tcount> ttable (4.614> 2.093) can be concluded, it can be concluded that artially the NPL variable (X2) has a significant effect on bank financial performance $(\mathrm{Y})$

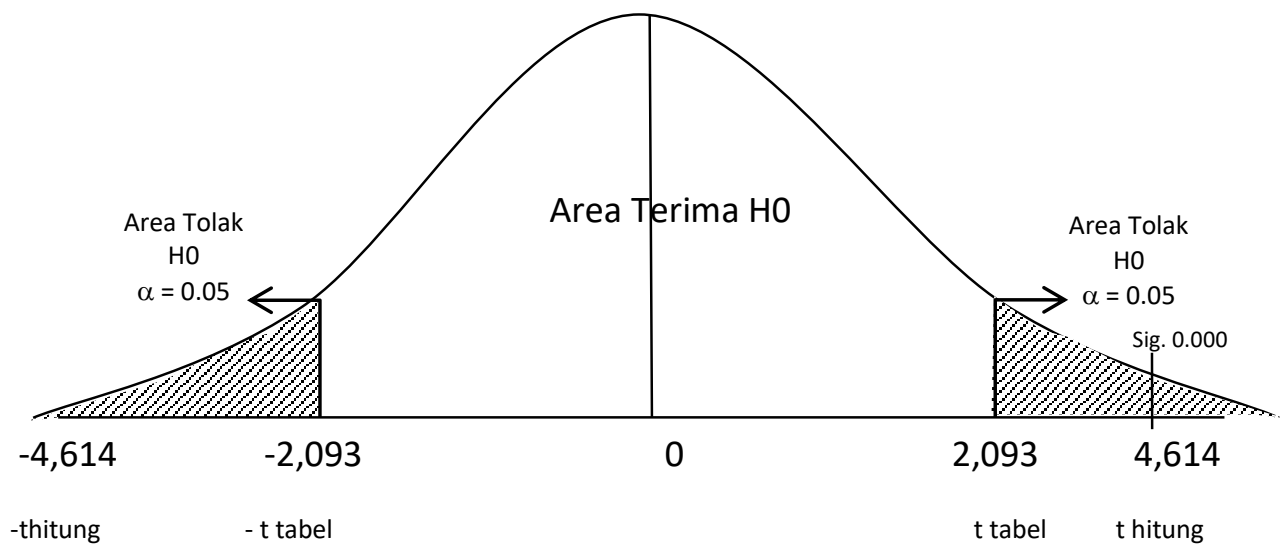




\subsubsection{ROA}

From the t test, it is obtained that $t$ count (2.554) is greater than t table (2.093). So that tcount $>$ ttable then $\mathrm{H} 1$ is accepted. From these data, the value of tcount> ttable (2.554> 2.093) can be concluded, it can be concluded that partially the ROA variable (X3) has a significant effect on bank financial performance $(\mathrm{Y})$.

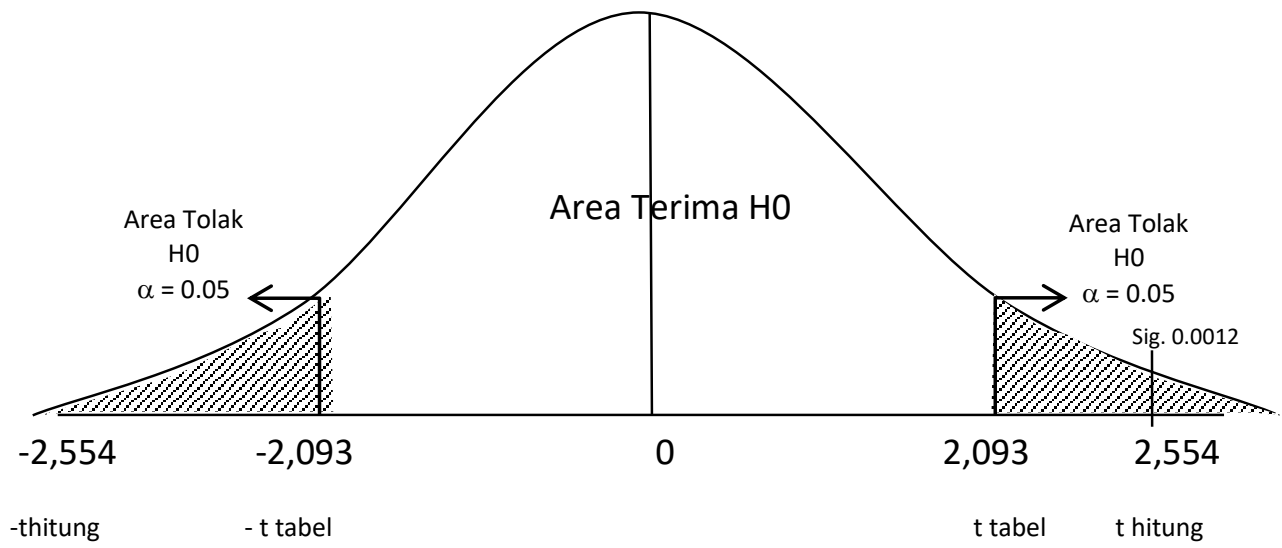

\subsubsection{NIM}

From the t test, it was obtained that $\mathrm{t}$ count (3.987) was greater than t table (2.093). So that tcount $>$ ttable then $\mathrm{H} 1$ is accepted. From these data, the value of tcount $>$ ttable (3.987> 2.093) can be concluded, it can be concluded that partially the NIM variable (X4) has a significant effect on bank financial performance $(\mathrm{Y})$.

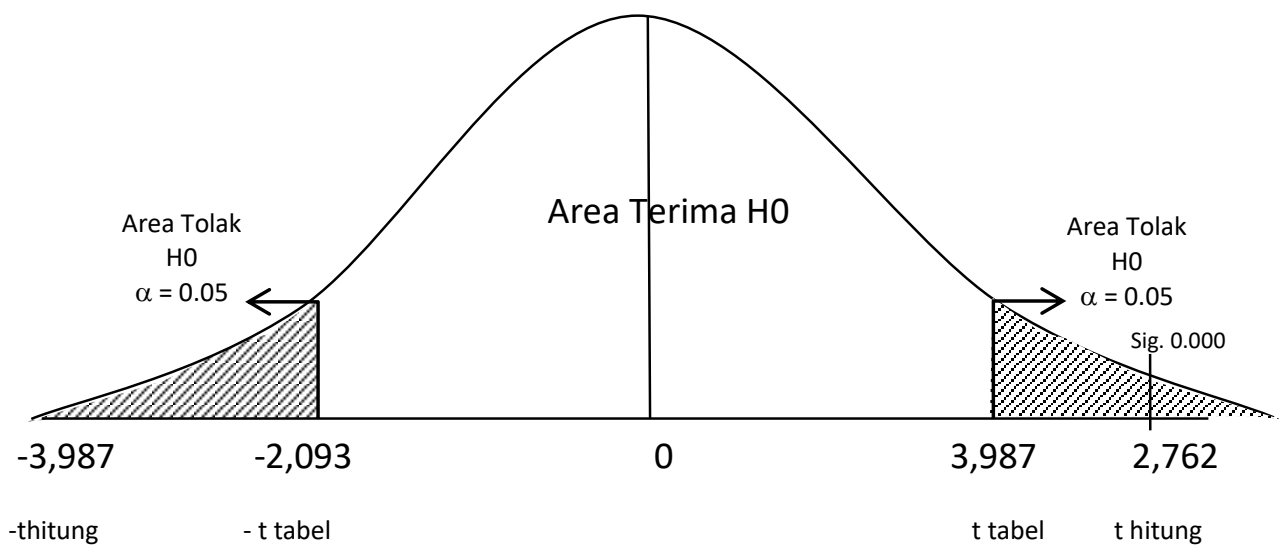

\subsection{5. $L D R$}

From the t test, it is obtained that $t$ count (2.427) is greater than $t$ table (2.093). So that tcount $>$ ttable then $\mathrm{H} 1$ is accepted. From these data, the value of tcount> ttable (2.427> 2.093) can be concluded, it can be concluded that partially the LDR variable (X5) has a significant effect on bank financial performance $(\mathrm{Y})$. 


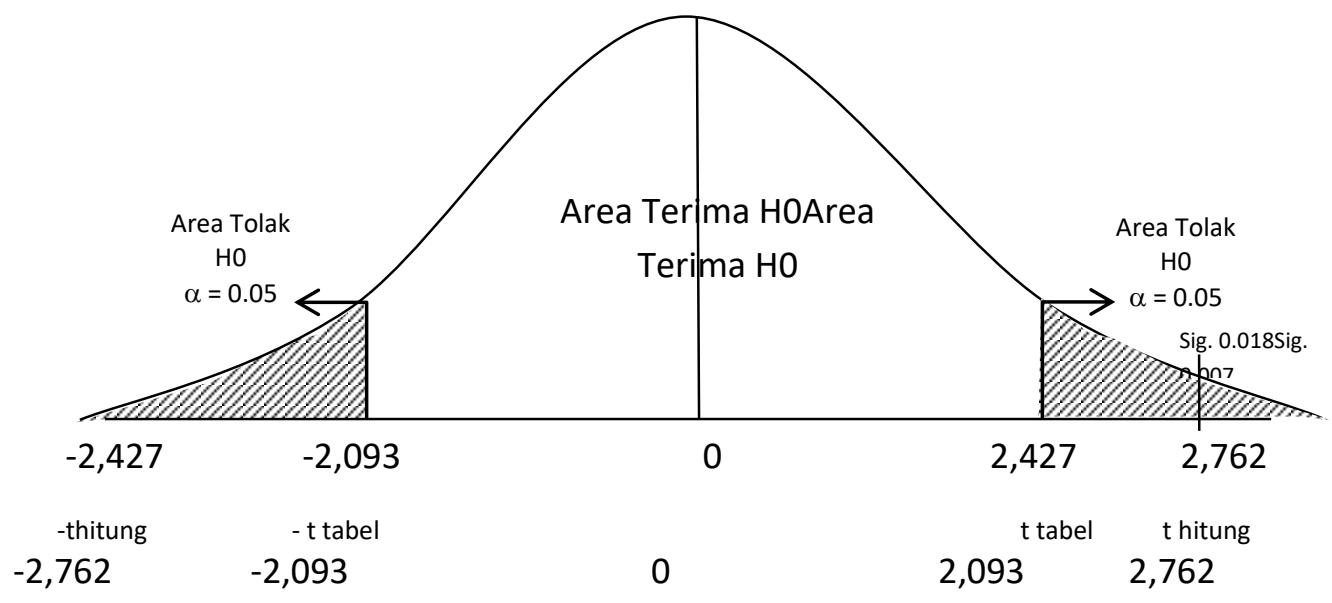

\subsection{F test}

Based on the results of the $\mathrm{F}$ test above with a significant value $\alpha=0.05, \mathrm{df}=\mathrm{n}-\mathrm{k}(25-5=20)$ obtained Ftable (2.7109), with the following analysis:

Table 2. F Test Results

\begin{tabular}{|c|c|c|c|c|c|c|}
\hline \multicolumn{7}{|c|}{ ANOVA $^{\mathrm{a}}$} \\
\hline \multicolumn{2}{|c|}{ Model } & Sum of Squares & $\mathrm{df}$ & Mean Square & $\mathrm{F}$ & Sig. \\
\hline \multirow[t]{3}{*}{1} & Regression & 271,035 & 5 & 90,345 & 40,966 &, $000^{\mathrm{b}}$ \\
\hline & Residual & 211,715 & 96 & 2,205 & & \\
\hline & Total & 482,750 & 99 & & & \\
\hline
\end{tabular}

a. Dependent Variable: Kinerja Keuangan Bank

b. Predictors: (Constant), CAR, NPL, ROA, NIM, LDR

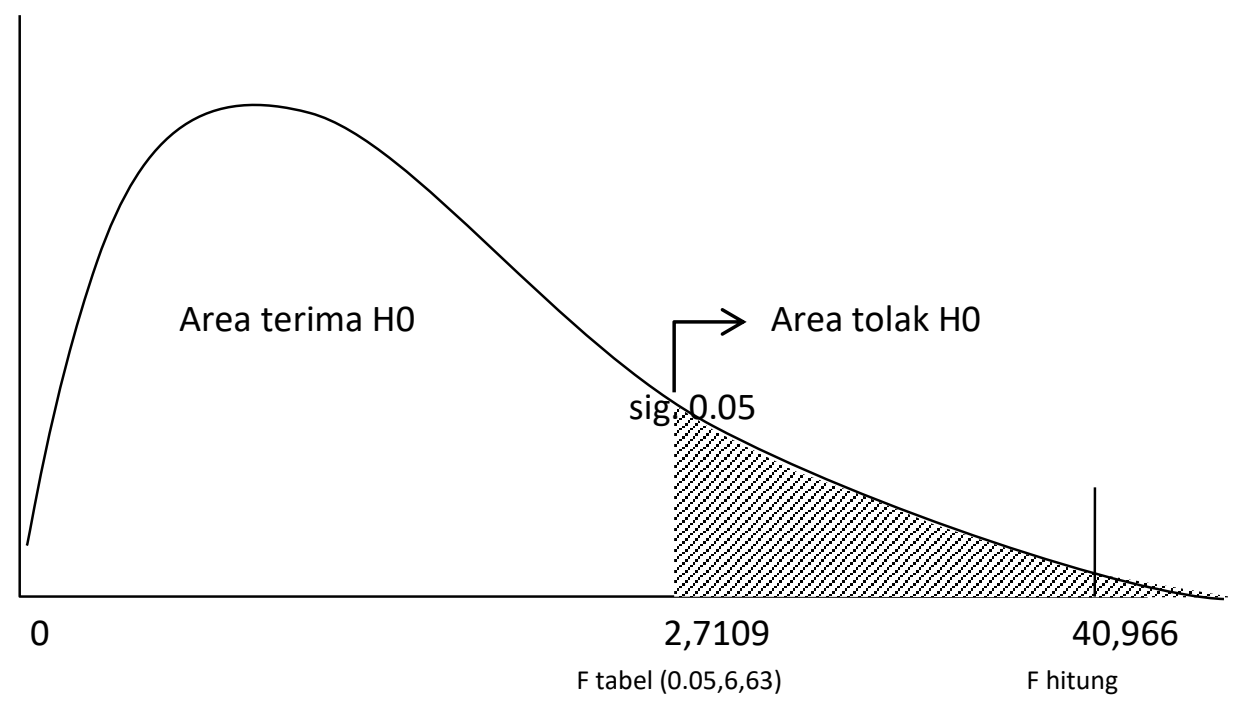


From the $\mathrm{F}$ test, it is obtained that Fcount (40.966) is greater than Ftable (2.7109). So that Fcount> Ftable then $\mathrm{H} 1$ is accepted. From these data, it can be concluded that the value of Fcount> Ftable (40.966>
2.7109), it can be concluded that the simultaneous significant effect on bank financial performance $(\mathrm{Y})$.

\subsubsection{Uji Dominan}

Tabel 3. Hasil Uji Dominan

\begin{tabular}{|l|l|r|rr|}
\hline \multirow{2}{*}{\multicolumn{2}{|c|}{}} & \multicolumn{3}{|c|}{ Unstandardized Coefficients } \\
\cline { 3 - 5 } Model & \multicolumn{2}{|c|}{ Std. Error } \\
\hline \multirow{4}{*}{1} & (Constant) & B &, 891 & 2,960 \\
\cline { 2 - 5 } & CAR (X1) &, 303 &, 110 \\
\cline { 2 - 5 } & NPL (X2) &, 421 &, 091 \\
\cline { 2 - 5 } & ROA (X3) &, 249 &, 098 \\
\cline { 2 - 5 } & NIM (X4) &, 377 &, 094 \\
\cline { 2 - 5 } & LDR (X5) &, 304 &, 125 \\
\hline
\end{tabular}

From the results of the coefficients of the independent variables above are positive. This means that it has a direction of change in the same direction as the dependent variable. The regression coefficient for the NPL variable is 0.421 , which has the largest value compared to other independent variables. Thus it can be concluded that the most dominant factor affecting financial performance is NPL.

\subsubsection{Koefisien Determinasi}

Tabel 4. Hasil Uji Koefisien Determinasi

Model Summary ${ }^{\mathrm{b}}$

\begin{tabular}{|c|c|c|c|c|c|}
\hline Model & $\mathrm{R}$ & R Square & Adjusted R Square & $\begin{array}{l}\text { Std. Error of the } \\
\text { Estimate }\end{array}$ & Durbin-Watson \\
\hline 1 & ,749 & ,561 & ,548 & 1,485 & 1,430 \\
\hline
\end{tabular}

a. Predictors: (Constant), CAR, NPL, ROA, NIM, LDR

b. Dependent Variable: Kinerja keuangan Bank

Source: Spss 26 Output Results

Based on the coefficient of determination test in the table, the $\mathrm{R}$ Square value is 0.561 or $56.1 \%$, this indicates that the dependent variable on the bank's financial performance can be explained by the independent variables CAR (X1), NPL (X2), ROA (X3), NIM (x4) and LDR (X5) of 56.1\% while the remaining $43.9 \%$ is explained by other factors outside the model in this study.

\section{CONCLUSION}

From the results above, it can be concluded the coefficients of the independent variables above are positive. This means that it has a direction of change in the same direction as the dependent variable. The regression coefficient for the NPL variable is 0.421 , which has the largest value compared to other independent variables. Thus it can be concluded that the most dominant factor affecting financial performance is NPL. From the $t$ test, it is obtained that $t$ count is greater than $\mathrm{t}$ table (2.093). So that tcount> ttable then $\mathrm{H} 1$ is accepted. So it can be concluded that partially the CAR, NPL, ROA, NIM, and LDR variables have a significant effect on bank financial performance (Y). And, from the F test, it is obtained that Fcount (40.966) is greater than Ftable (2.7109). So that Fcount> Ftable then H1 is accepted. From these data, it can be concluded that the 
value of Fcount> Ftable (40.966> 2.7109), it can be concluded that the simultaneous significant effect on bank financial performance (Y).

\section{REFERENCES}

[1] Cecaria Mega Tiara, 2015., Analisis Faktor-Faktor yang Membentuk Kinerja (CAMELS) pada Perbankan Indonesia: (Studi Empiris pada Perbankan yang Terdaftar di BEI Periode 20092012) [ Analysis of the Factors that Shape Performance (CAMELS) in Indonesian Banking: (Empirical Study on Banks Listed on the IDX for the Period 2009-2012)], Thesis, Fakultas Ekonomika dan Bisnis Universitas Diponegoro, Semarang

[2] Dewi, dkk, 2015., Analisis Pengaruh NIM, BOPO, LDR, dan NPL terhadap Profitabilitas (Studi Kasus pada Bank Umum Swasta Nasional yang Terdaftar Pada Bursa Efek Indonesia Periode 2009-2013) [Analysis of the Effect of NIM, BOPO, LDR, and NPL on Profitability (Case Study on National Private Commercial Banks Listed on the Indonesia Stock Exchange 2009-2013 Period). e-Journal S1 Ak. Universitas Pendidikan Ganesha Jurusan Akuntansi Program S1 (Volume: 3 No. 1 Tahun 2015).

[3] Fahmi, Irham. 2014. Analisis Kinerja Keuangan [Financial Performance Analysis]. Bandung: Alfabeta.

[4] Kurniasari Christiana, 2013., Analisa Pengaruh Rasio CAMEL dalam Memprediksi Finacial Distress Perbankan Indonesia [Analysis of the Effect of CAMEL Ratio in Predicting Financial Distress in Indonesian Banking], Thesis, Fakultas Ekonomika dan Bisnis Universitas Diponegoro, Semarang

[5] Margareta Farah, 2017., Faktor-Faktor yang Mempengaruhi Kinerja Perbankan di Indonesia [Factors Affecting Banking Performance in Indonesia], Volume 6 No. 2 Mei 2017, ISSN : 2089 - 3477, Fakultas Ekonomi, Universitas Trisakti.

[6] Prastowo, Dwi. 2015. Analisis Laporan Keuagan [Financial Statement Analysis]. Yogyakarta : Unit Penerbit dan Percetakan Sekolah Tinggi Ilmu Manajemen YKPN.

[7] Said, dkk (2016)., An analysis on the factors affecting profitability level of Sharia banking in Indonesia, Banks and Bank Systems, Volume 11, Issue 3, 2016, Faculty of Economics and Business
State Islamic University Syarif Hidayatullah Jakarta, Indonesia.

[8] Syairozi, M. I. (2021). Analisis Kemiskinan di Sektor Pertanian (Studi Kasus Komoditas Padi di Kabupaten Malang) [Analysis of Poverty in the Agricultural Sector (Case Study of Rice Commodities in Malang Regency)].Media Ekonomi, 28(2), 113-128.

[9] Syairozi, M. I. (2019). Keterkaitan Variasi Produk dan Tenaga Kerja Terhadap Peningkatan Laba Bengkel AHAS PANDAAN [The Relation of Product Variations and Labor to Increase in Profit at AHAS PANDAAN Workshop].

[10] Wicaksana Rizki Ludy, 2011., Analisis Pengaruh Rasio CAMEL terhadap Kondisi Bermasalah pada Sektor Perbankan di Indonesia [Analysis of the Effect of the CAMEL Ratio on Problematic Conditions in the Banking Sector in Indonesia], Thesis, Fakultas Ekonomi Universitas Diponegoro, Semarang 